\title{
Россия как участник \\ международных конфликтов в повестке массмедиа Швейцарии
}

\author{
Кристина Долголаптева
}

В статье рассматриваются факторы, влияющие на формирование образа России как участника международных конфликтов в повестке швейцарских франкоязычных массмедиа. Актуальность работы обусловлена изучением швейцарского опыта журналистской деятельности в условиях политической нестабильности и глобального информационного противоборства. В рамках исследования автор провел контент-анализ текстов крупных массмедиа, а также проанализировал публикации изданий по критериям «мирной журналистики» Й. Галтунга.

Ключевые слова: образ России, швейцарские массмедиа, международные конфликты. (с Долголаптева Кристина Олеговна магистрантка кафедры зарубежной журналистики и литературы факультета журналистики МГУ имени М.В. Ломоносова (г. Москва, Россия), k.dolgolapteva@yandex.ru

\section{Введение}

Освещение международных конфликтов средствами массовой информации Швейцарии представляет большой интерес для анализа. Согласно данным Reporters Without Borders за 2019 г., Швейцария занимает шестое место в рейтинге стран по уровню свободы прессы1․ Однако изучению стереотипизированности мышления швейцарских журналистов, выработанной под влиянием антироссийской риторики в медиадискурсе стран Запада, посвящено сравнительно небольшое количество работ. В рамках данного исследования мы опирались на источники, рассматривающие проблемы "мирной журналистики» (Galtung, 2002; McGoldrick, Lynch, 2000; Aguirre, Ferrándiz, 2002; Якова, 2018 (а, б)), своеобразие медиасистемы Швейцарии (Якова, 2010, 2013, 2016, 2017; Краснова, 2012; Быкова, 2001; Тимошенко, 2011), а также основы эмпирических исследований в сфере СМИ (Фомичева (ред.), 2011; Федотова, 2001).

В Швейцарии законодательно признаны официальными четыре языка. Французский является вторым по значимости государственным языком в этой стране (на первом месте немецкий, на третьем и четвертом итальянский и ретороманский языки соответственно) ${ }^{2}$. Языковое разнообразие предполагает диверсификацию контента 
внутри швейцарской медиасистемы. Она действует по принципу "для многообразия равное обращение» (McQuail, 2010: 167), т.е. франкоязычный гражданин должен получать информацию в том же объеме, что и немецкоязычный, италоязычный или ретороманоязычный.

Как страна, сохраняющая постоянный нейтралитет и ставящая перед собой задачу налаживать мирный диалог между разными странами, Швейцария должна непредвзято освещать в национальной прессе международные конфликты, не защищая позиций ни одной из враждующих сторон. Однако, согласно результатам проведенного нами исследования 4 , в 44\% аналитических материалов, посвященных действиям России в урегулировании международных конфликтов, журналисты прямо (посредством стилистически окрашенной лексики) или косвенно (с помощью приемов имплицитного ввода информации) занимали сторону одного из участников конфликта. Для выборки по методу ключевых слов за исследуемый период были отобраны 356 материалов из следующих изданий: Le Temps - 195, La Liberté - 93, Le Courrier 68. Обращалось также внимание на жанровое своеобразие: аналитические статьи и корреспонденции, аналитические статьи с элементами интервью или репортажа, а также новости с лент информационных агентств. Были рассмотрены публикации об инциденте в Керченском проливе, об урегулировании ситуации в Афганистане, о России как участнике войны в Сирии, об участии российских военных в гражданской войне в Ливии, о выходе США из ДРСМД и роли России в этом процессе. Опираясь на результаты исследования, мы выявили тренды в области применения манипулятивных приемов в независимых и нейтральных, а по факту предвзятых в своих оценках изданиях, определили факторы, влияющие на формирование негативного образа России.

\section{Оценка действий России в западной информационной повестке}

В условиях мировой политической нестабильности и глобального информационного противоборства Россия как актор международных отношений вынуждена вырабатывать собственную позицию касательно общемировых проблем, в том числе и вооруженных конфликтов в различных регионах в соответствии со своей национальной безопасностью, а также нормами международного права. Возникновение и развитие современных вооруженных противостояний является следствием крайне неустойчивой системы миропорядка.

В силу разных причин в 2018 г. - начале 2019 г. Россия опосредованно участвовала в следующих противостояниях: кризис на Украине, гражданская война в Сирии, в Центральноафриканской Республике, в Ливии; конфликт в Косово, в Нагорном Карабахе, в Западной Сахаре, война в Афганистане. С точки зрения российских политических платформ, официальных документов различных государственных ведомств, действия России в вооруженных конфликтах направлены на установление мира. Однако ее позиция по многим вопросам не всегда совпадает с представлениями мироустройства других государств, в частности США, из-за чего возникает довольно ожесточенная полемика в западной прессе насчет правомерности тех или иных действий России и ее союзников. Несмотря на ориентированность медиасистемы Швейцарии в большей степени на локальные инфоповоды, швейцарские массмедиа отражают и международную повестку, нередко посвящая материалы анализу действий России в конфликтных ситуациях (см. рис. 1-3).

Логично предполагать, что средства массовой информации Швейцарии должны освещать не только локальные вопросы, но и международные проблемы с позиций мирного урегулирования напряженных 


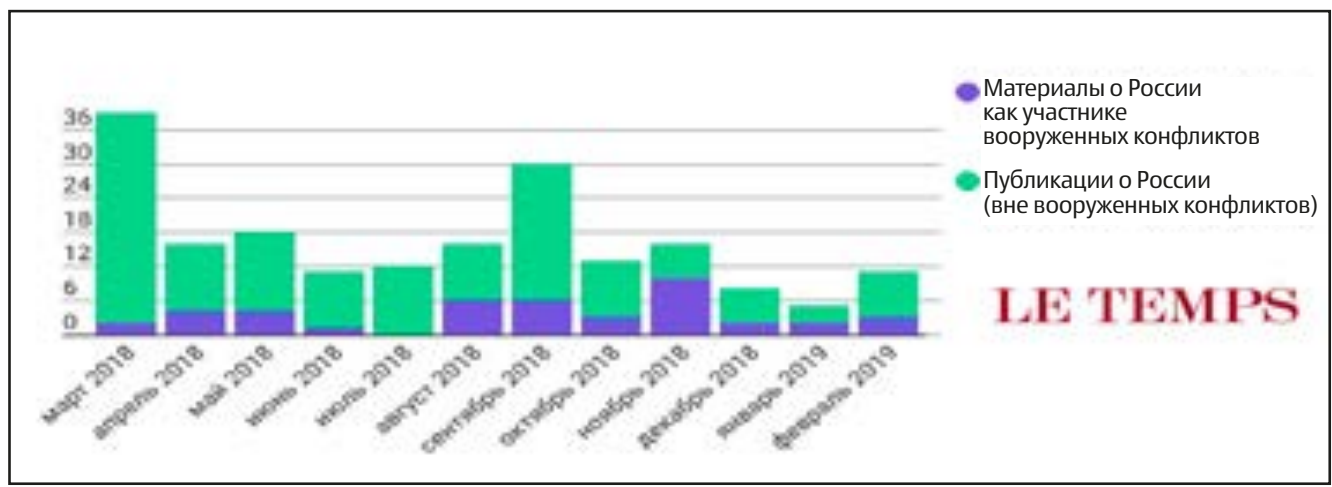

Рисунок 1. Частотный анализ публикаций газеты Le Temps

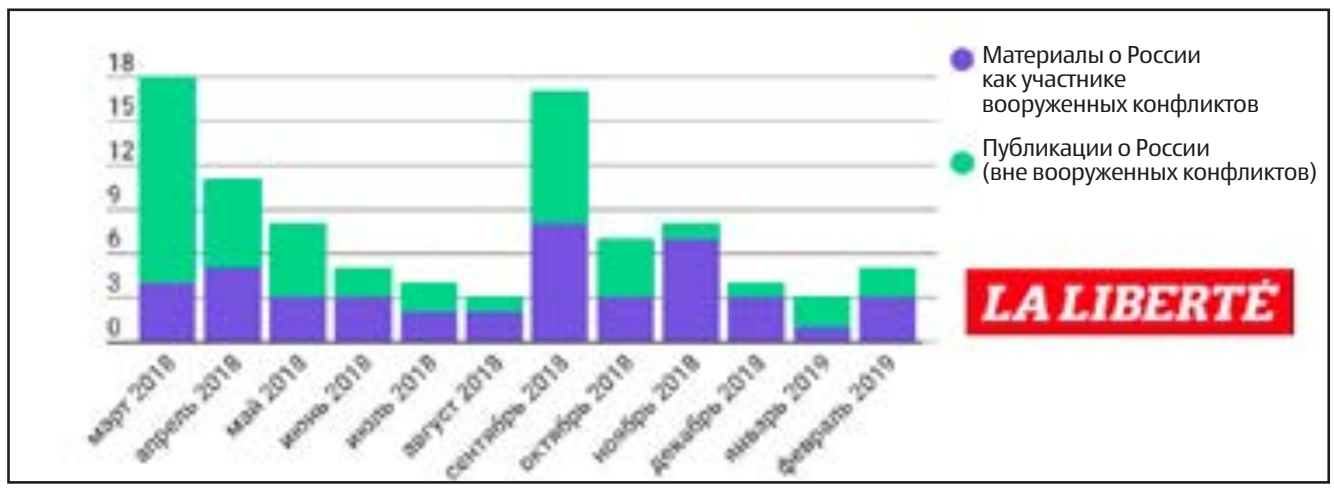

Рисунок 2. Частотный анализ публикаций газеты La Liberté

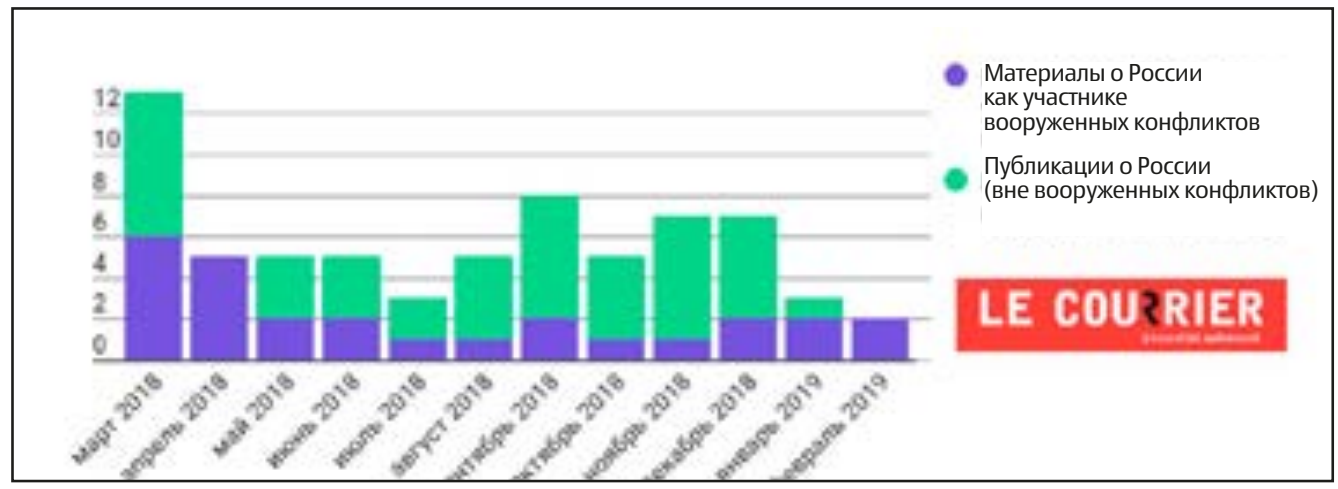

Рисунок 3. Частотный анализ публикаций газеты Le Courrier 
ситуаций. Эта роль максимально соответствует исторически сложившимся особенностям медиасистемы, рассматриваемой нами страны. Д. Халлин и П. Манчини (2004: 143-145) относят швейцарскую систему массмедиа кдемократической корпоративистской модели, которой присущи историческая обусловленность свободы прессы, политический плюрализм, активное влияние государства при защищающем свободу слова законодательстве, журналистский профессионализм, развитое общественное телевидение и радиовещание, наличие независимых локальных газет.

Исследование этих авторов не утратило своей актуальности и сегодня, но швейцарской медиасистеме также свойственен ряд отличительных (в том числе проблемных) нюансов: высокий уровень влияния кантональных массмедиа при отсутствии национальных изданий, большие тиражи бесплатных газет при общем уменьшении числа подписчиков, проблема концентрации СМИ и исчезновение качественной и расследовательской журналистики из-за принятых издательствами мер экономии в результате сокращения доходов от рекламы ${ }^{5}$. Это определяет некритичное восприятие швейцарскими журналистами западных оценок действий России в урегулировании международных конфликтов.

\section{Исторические особенности дипломатических отношений России и Швейцарии}

То, что может быть расценено как солидаризация с мнением Запада и как нежелание самостоятельно анализировать мотивацию России при участии в международных процессах, вытекает из истории дипломатических отношений России и Швейцарии. В большей части изученных нами источников отмечается, что отношения этих стран никогда не доходили до открытого противостояния. Однако эта характеристика в большей степени относится к отношениям царской России и Швейцарии (до сих пор швейцарцы с благодарностью вспоминают подвиг русского полководца А. Суворова в Альпах). B XX в. дипломатические отношения между коммунистической РСФСР и буржуазной Швейцарией ухудшились, а затем были разорваны из-за убийства полпреда В. Воровского (1923 г.), который приехал на Лозаннскую конференцию по Черноморским проливам как глава советской делегации (к слову, секретариат конференции не признал дипломатов в качестве полноценных участников). Не дождавшись даже извинений от швейцарской стороны, ВЦИК и Совнарком выпустили декрет «О бойкоте Швейцарии». Только после окончания Второй мировой войны, признавая заслугу Советского Союза в борьбе с фашизмом, в 1946 г. Швейцария снова стала открыта для дипломатических контактов ${ }^{6}$. Последствия этих событий ощутимы и сегодня: «Швейцарии исторически свойственен прозападный уклон. Антикоммунистическая пропаганда нашла здесь очень плодородную почву в XXв. Швейцарская элита постоянно вела двойную игру: нейтралитет, чтобы иметь возможность торговать со всеми, антикоммунизм - для защиты своих классовых интересов. Даже после распада СССР этот процесс продолжается, поскольку он в той же степени соответствует колониальному видению мира, <...> швейцарец будет чувствовать себя ближе к австралийцу, чем к русскому. По убеждению и/или маркетинговому интересу газеты интерпретируют действия России в негативном ключе»7, - отметил редактор международного отдела газеты Le Courrier Б. Перез.

\section{Гибкая трактовка принципа нейтралитета}

Несмотря на деятельность институтов международного гуманитарного права, миротворческих организаций по предотвра- 
щению и урегулированию конфликтов, «государства Европы в современных условиях не отказываются от военной силы как средства сдерживания потенциальной угрозы. В условиях, когда уровень интеграции и взаимной зависимости государств очень высок, исключительно коллективные усилия способны предотвратить возникновение опасностей» (Умеренко, 2011: 2). Швейцарская Конфедерация взяла на себя ответственность способствовать мирному урегулированию международных конфликтов, выполняя роль посредника между утратившими дипломатические отношения странами и помогая им наладить друг с другом диалог. Ошибочно предполагать, что на развитие миротворческой позиции Швейцарии повлиял принцип нейтралитета в его классическом понимании, поскольку он предполагает полную неангажированность во внешнеполитических вопросах ${ }^{8}$.

Швейцария оформила постоянный нейтралитет в 1815 г., подписав четыре международных договора. Это был логичный итог развития государства, поскольку предпосылки швейцарского нейтралитета начали формироваться уже в XV-XVI вв. Понимание принципа нейтралитета регулярно менялось, его трактовка становилась все более гибкой: «Основные положения нейтралитета остаются неизменными, но расширение определения нейтралитета как внешнеполитического курса и его применения в военное время дает существенный стимул к развитию нейтралитета и закреплению его как в области международного права, так и в политической сфере» (Фокина, 2016). Военный нейтралитет Швейцарии ни в Первую мировую войну (немецкоязычные швейцарцы неформально поддерживали Тройственный союз, франкоязычные - Антанту), ни в период Второй мировой войны (сбивали самолеты, которые нарушали воздушное пространство Швейцарии и обстреливали города) не предполагал нейтральности позиции ее жителей (Драгунов, 1978). Это отчасти связано с новой, подразумевавшей заинтересованность в урегулировании внешнеполитической ситуации трактовкой принципа нейтралитета, которую предложил швейцарский дипломат и преподаватель международного права Цюрихского университета Х.М. Хубер (Fischer, Möckli, 2016). Во многом закреплению понятия активного нейтралитета способствовало вступление Швейцарии в ООН, поскольку Устав этой организации предполагает, что ее члены не могут оставаться нейтральными во время конфликта (Тиунов, 1968).

\section{О роли информационных агентств в формировании повестки дня}

Обладая высоким уровнем свободы слова (стоит учитывать, что в рейтингах анализируется степень вмешательства государства и бизнеса в деятельность редакций, но не рассматривается факт подконтрольности журналистов официальной идеологии массмедиа), швейцарские издания тем не менее не претендуют на объективность и качество в плане освещения международных проблем. Некоммерческий проект Swiss Propaganda Research разместил на своем сайте исследование об освещении международных новостей в швейцарских массмедиа. По мнению авторов, основной проблемой международной повестки дня является заимствование журналистами сообщений из лент крупных (Associated Press, Reuters, Agence France-Presse) информационных агентств 9 . Эта тенденция (в основном) прослеживается и в вышепредставленных изданиях (см. рис. 4, 5). Исследователи отмечают некачественную работу редакторов, которые дублируют новость из ленты информагентства, всего лишь добавляя изображение, видео или же изредка дополняя ее информацией, объясняющей позицию издания по освещаемой проблеме. Схожесть формулировок, в том числе заголовков, авторы также объясня- 
ют копированием сообщений: «Зависимость от глобальных агентств создает поразительное сходство в международной отчетности: от Вены до Вашингтона наши СМИ часто освещают одни и те же темы, используя множество одинаковых фраз, явление, которое в противном случае было бы связано с контролируемыми СМИ в авторитарных государствах»10.

Доверие глобальным информационным агентствам оборачивается большой проблемой, поскольку информация о событиях из других источников (даже первоисточников), не отраженная на ленте информагентств, не расценивается швейцарскими массмедиа как достоверная и достойная внимания. В декабре 2016 г. на независимом телеканале Kla.tv вышел сюжет, посвященный утаиванию международной информации на примере игнорирования журналистами крестного хода, организованного 27 июля 2016 г. Украинской православной церковью Московского патриархата. Мирное шествие было организовано с целью убедить киевское правительство прекратить войну в Донбассе. Сведения об этом мероприятии не появлялись на лентах информационных агентств, из-за чего событие не было освещено в швейцарских массмедиа"1.

Действительно, в материалах франкоязычных СМИ, посвященных реакции России на какое-либо событие, журналисты ссылаются не на первоисточники (ТАСС, сообщения МИДа РФ и т.д.), а на французское информационное агентство Agence France-Presse (AFP)12. Мы бы объяснили мотивацию журналистов не только доверием к французским коллегам, но и возможностью оперативно размещать материал на сайте, поскольку в отличие от русскоязычного первоисточника, сообщения AFP уже подготовлены для публикации и не требуют перевода.

Эти негативные особенности тесно связаны с экономическими проблемами у из- даний, считает редактор международного отдела газеты Le Courrier Б. Перез: «Даже такая богатая газета, как Le Temps, борется за то, чтобы иметь в России штатного корреспондента (см. рис. 6). Кроме того, количество международных отделений в Лозанне значительно сократилось. Использование агентских рассылок (AFP, Reuters, AP) мотивировано бюджетными соображениями, экономической рентабельностью издания»13. Чтобы восполнить лакуны международной повестки, в Швейцарии существует практика, когда газеты имеют общих иностранных корреспондентов, работающих вне штата, а также обмениваются материалами с газетами-партнерами: «У нас есть партнерские отношения с другими газетами, которые делятся с нами статьями своих иностранных корреспондентов. Мы сотрудничаем с Le Monde Diplomatique, La Liberté, Libération»14. Это позволяет говорить о взаимозаменяемости изданий: читателю не обязательно подписываться на несколько газет, чтобы узнавать альтернативные точки зрения и делать выводыс опорой на личный опыт и понятия. Полное дублирование новости информационного агентства на сайтах и в печатных версиях разных изданий не только не считается предосудительным, но и поддерживается издателями.

\section{Превалирование «журналистики войны и насилия" над «мирной журналистикой»}

Современные средства массовой информации являются полноценными участниками международных конфликтов, поскольку большая часть публикуемых ими сообщений о конфронтациях поляризует общественное мнение, в результате чего вооруженный международный конфликт приобретает глобальное значение.

Методы и способы урегулирования противостояния посредством публикаций в массмедиа рассматривает теория «мирной 


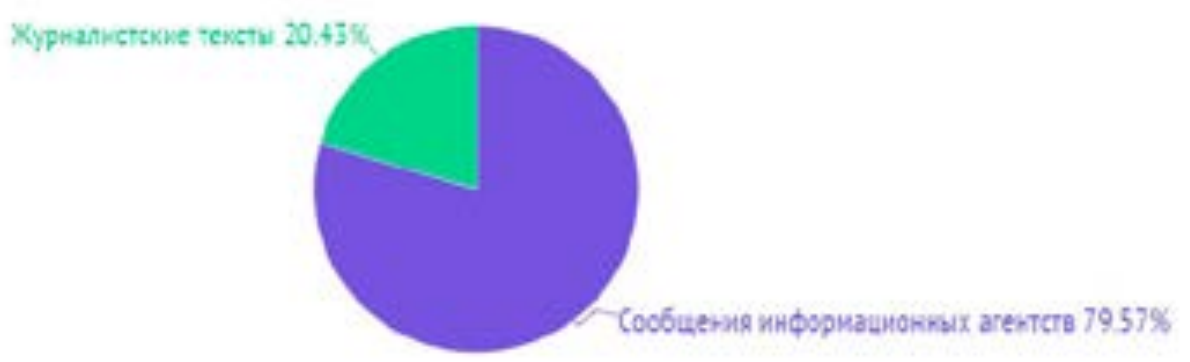

Рисунок 4. Соотношение материалов по типу авторства в газете La Liberté

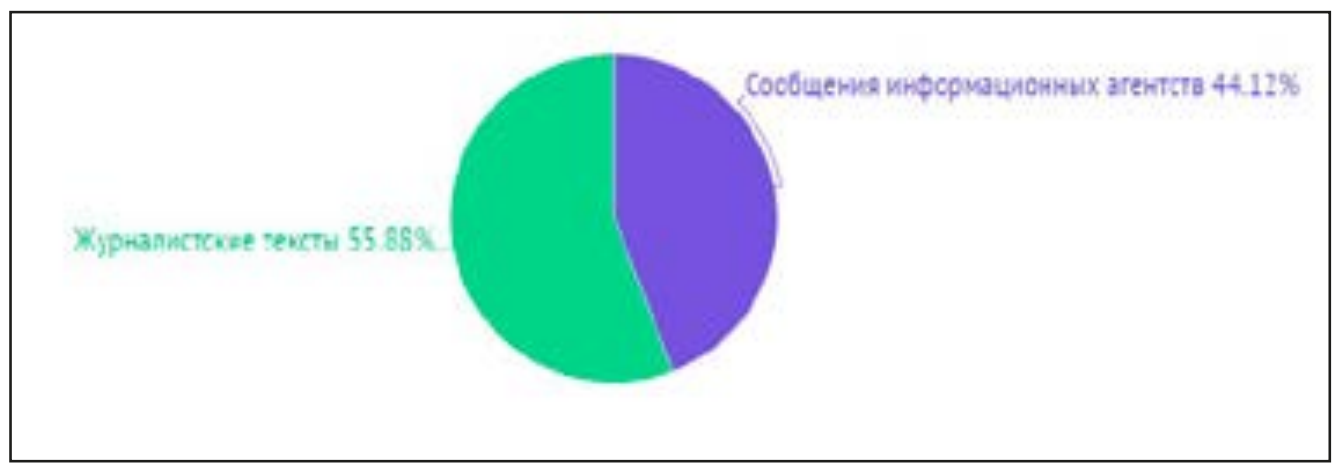

Рисунок 5. Соотношение материалов по типу авторства в газете Le Courrier

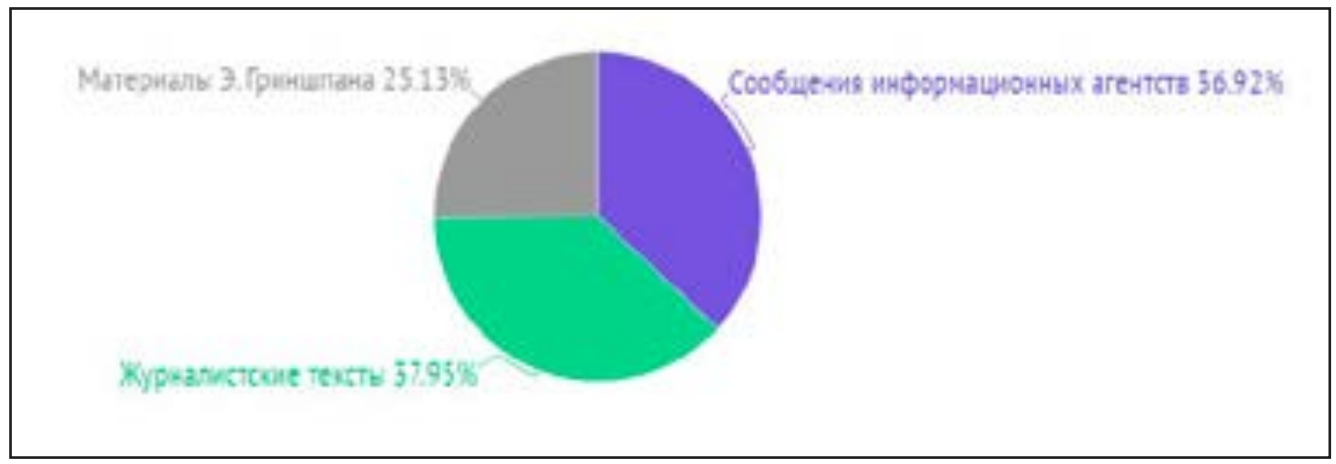

Рисунок 6. Соотношение материалов по типу авторства в газете Le Temps (материалы специального корреспондента в Москве Э. Гриншпана формируют четверть информационной повестки о действиях России) 


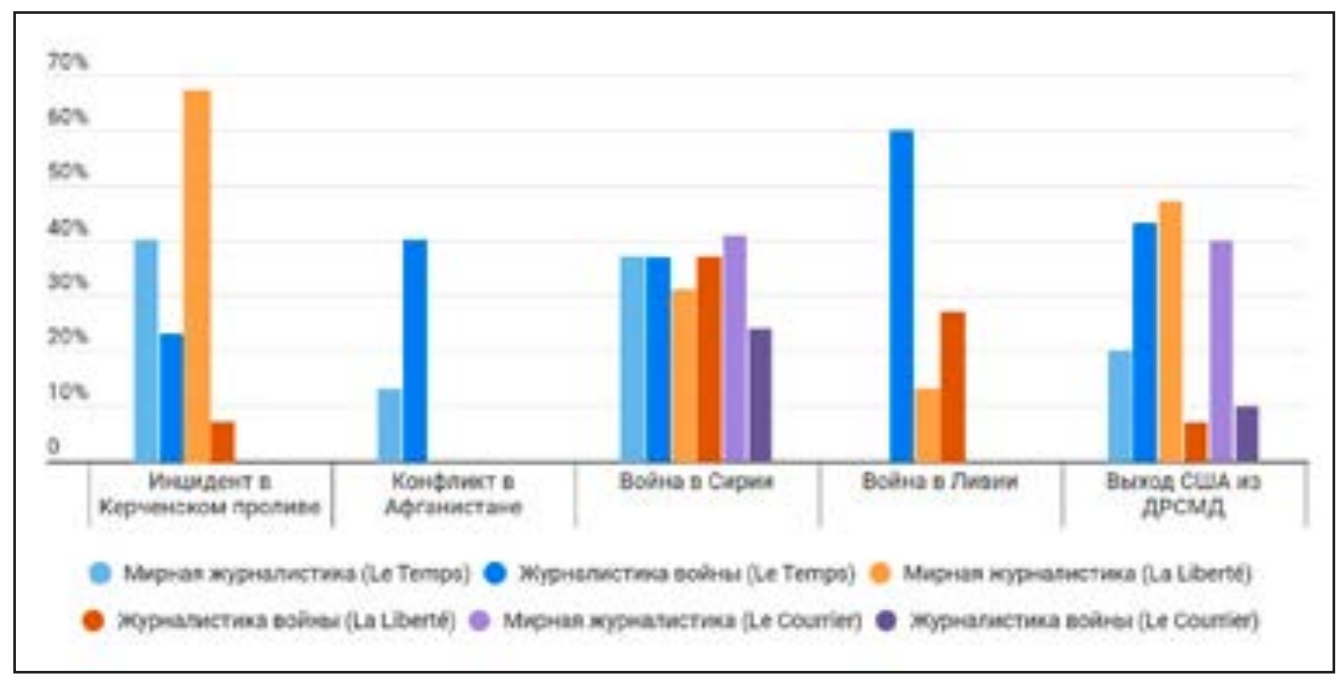

Рисунок 7. Процентное соотношение публикаций на соответствие критериям «мирной журналистики» и «журналистики войны»

журналистики», которая была разработана норвежским социологом и исследователем медиа Й. Галтунгом (2000). Согласно теории, массмедиа должны вырабатывать у аудитории гуманное отношение к представителям обеих сторон и предлагать различные варианты мирного разрешения конфронтации.

Противоположностью «мирной журналистики» является “журналистика войны и насилия», которая подразумевает такую деятельность массмедиа, которая формирует образ врага одной из сторон и тем самым способствует эскалации конфликта. По мнению Й. Галтунга (2000: 163), «мирная журналистика» характеризуется тем, что не разделяет людей по принципу «свой-чужой», а также отличается от военной своей прозрачностью: «Задача "мирной журналистики" - сделать конфликт прозрачным; задача "военной журналистики" - сохранить военную тайну".

В рамках данной работы автор рассмотрел публикации по основным критериям анализа медиатекстов в соответствии с теорией «мирной журналистики»: нали- чие позитивных или негативных маркеров, ангажированность СМИ, плюрализм мнений, экспрессивная оценочная лексика, нацеленность на выработку мирных решений. Выборка осуществлялась на основе публикаций, внесенных в таблицы для контент-анализа; материалы для анализа по критериям «мирной журналистики» должны были соответствовать следующим условиям: текст относится к аналитическому жанру и посвящается определенной проблеме, резвившейся в ходе международного конфликта, имеет автора, в тексте прослеживается трактовка события в позитивном, негативном или нейтральном ключе, действия России могут не являться основной темой статьи, но быть частью комплексного анализа текущей обстановки международного конфликта.

Американский теоретик массмедиа Н. Постман еще в середине 1980 гг. говорил о дискретности и фрагментарности информации, ее оторванности от контекста. Актуальность этой книги сложно переоценить, поскольку глава "А теперь..." (Now... This) как нельзя лучше объясняет 
современные тренды транслирования и восприятия новостей. Исследователь заявляет, что фраза «а теперь...", ставшая в новостных телевизионных программах особой связкой, «которая ничего ни с чем не соединяет, а наоборот, совершает противоположное, отделяет все от всего, <...> есть некий способ признать факт, что мир, каким его рисует массмедиа, не имеет ни порядка, ни смысла, и его не стоит воспринимать всерьез» (Postman, 1985: 118). По мнению Н. Постмана, развлечение сегодня стало единственным способом передачи информации.

Новости о войне и насилии являются частью развлечения. Фраза «а теперь...» подходит электронным массмедиа даже больше, чем телевидению, поскольку читатель может потреблять предлагаемую информацию нелинейно и с учетом своих потребностей и интересов. В еще большей степени это относится к лентам социальных сетей, где алгоритм сам определяет, какой именно информации достоин пользователь, не заботясь о том, что серьезная информация об эскалации конфликта будет идти после очередного мема. Вероятно, привлечь внимание к международной повестке интересующихся внутренней политикой и активно потребляющих развлекательный контент швейцарцев можно только такими материалами, в которых акценты смещены в сторону насилия и создания образа врага.

Если предполагать, что общество (в частности швейцарское) нуждается в создающих образ врага материалах как новом типе развлекательного контента, то у теории «мирной журналистики» есть существенный недостаток. Она не учитывает, что читатель не воспринимает войну и насилие как нечто ужасное. Как бы это не звучало цинично, для него слова «убит», «расстрелян», «пытка» несут тот же посыл, что и информация о новом моющем средстве. Наиболее показательным историче- ским случаем в этом плане было освещение в американских массмедиа войны во Вьетнаме (1955-1975): «По сути, это была первая в мире война, которую показывало телевидение, которая через телевизоры вошла в дом каждого американца. Телезрители были шокированы кадрами разрушенных вьетнамских городов и деревень, убийств военнослужащих и мирных жителей <...> Таким образом, средства массовой информации, и в первую очередь телевидение, вызвали во второй половине 1960 гг. мощное антивоенное движение по всем Соединенным Штатам» (Прутцков, 2018: 267). Это не значит, что сегодня нужно пересматривать принципы профессиональной журналистской этики, но этот факт может служить поводом для размышлений над тем, какой вред могут нести эвфемизмы и сокрытие ряда фактов.

\section{Заключение}

Формирование зарубежной повестки дня в швейцарских франкоязычных массмедиа связано с процессами интеграции отличающейся глокализованностью медиасистемы Швейцарии в глобальный информационный процесс. Результат контент-анализа показал, что, несмотря на относительно высокую частоту публикации формирующих образ России текстов (например, среднее количество ежедневных материалов издания Le Temps о России в течение рассматриваемого периода составляет 0,53 статьи), около половины из них (варьируется в диапазоне от 37\% до 80\%) составляют перепечатки сообщений из западных информационных агентств. Как следствие, международная повестка изданий в большинстве случаев отличалась невысоким качеством анализа происходящих событий.

Несмотря на авторитетность исследуемых нами газет, международные события освещались с акцентом на некоторую сенсационность; журналисты использо- 
вали устоявшиеся стереотипы о России и демонстрировали аудитории в своих текстах комичные, малопривлекательные «особенности" русского менталитета. При этом миротворческие инициативы России как участника международных конфликтов часто выпадали из повестки, не анализировались журналистами газет Le Temps, La Liberté и Le Courrier. К тому же из-за того, что франкоязычные массмедиа Швейцарии ориентированы на контент, предоставляемый крупными мировыми информационными агентствами, тематика и фактура материалов на международные инфоповоды в разных изданиях была примерно одинаковой. В большинстве случаев журналисты трактовали события с прозападных позиций; выдвигаемые Россией инициативы по мирному урегулированию конфликтов рассматривались ими как стратегический ход по расширению влияния в регионе.

В отличие от аналитических статей качество новостных заметок о России было невысоким: события были представлены в отрыве от контекста, вне хронологии (журналисты не дополняли одну новость о быстро развивающемся во времени событии, как это принято в современной журналистской практике, а публиковали несколько новых мало связанных друг с другом сообщений), авторы часто действовали посредством убеждения читателя, а не приглашения его к дискуссии, а также освещали события односторонне, без бэкграунда, что требовало от читателя хорошей информационной подготовки.

Аналитические статьи, посвященные роли России в урегулировании международных конфликтов, были проанализированы нами по критериям теории «мирной журналистики». Для такого анализа мы отобрали публикации о следующих событиях международных противостояний: инцидент в Керченском проливе, инициированные Москвой переговоры с афганской сторо- ной и вопрос пересмотра статуса террористической группировки «Талибан» (запрещена в РФ), провокации в Восточной Гуте в связи с применением химического оружия, соглашение между Россией и Турцией по мирному урегулированию ситуации в провинции Идлиб, вопрос переброски российских войск в Ливию и создание двух военных баз на подконтрольной Палате представителей Ливии территории, а также денонсация заключенного между СССР и США договора о ракетах средней и меньшей дальности.

Мы выявили закономерность: те инциденты, которые послужили поводом для написания большого количества аналитических статей, показали более соразмеренные графики (поскольку швейцарская пресса приветствует плюрализм мнений на своих страницах), в то время как менее освещаемые инфоповоды имели ярко выраженный перевес в сторону или «мирной журналистики», или «журналистики войны».

Журналисты, как правило, маркировали стороны посредством оценочной лексики. В большинстве случаев по отношению к действиям России и ее дипломатическим инициативам, которые Москва позиционировала как положительные и способствующие мирному урегулированию, применялась лексика с негативной коннотацией. Что касается региональных интересов швейцарских франкоязычных массмедиа, то они чаще анализировали роль России как участника конфликтов, в которых сильные позиции занимает как Россия, так и США (с этим связано подробное освещение войны в Сирии, в то время как ситуация в Афганистане с точки зрения предпринятых Россией мирных инициатив по урегулированию не получила такого масштабного журналистского отклика).

Частотный анализ материалов изданий продемонстрировал острую зависимость швейцарских франкоязычных массмедиа от западных информационных агентств, 
в частности французского информационного агентства AFP: газеты рассматривали одинаковые темы, солидаризировались в трактовке и оценках произошедшего (хотя стоит признать, что в аналитических статьях изредка были представлены и противоположные точки зрения на освещаемую журналистами проблему). Эти факторы, в свою очередь, отразились и на соответствии публикаций критериям теории «мирной журналистики».

Подводя итоги, отметим, что в течение анализируемого нами периода (март 2018 г. - февраль 2019 г.) франкоязычные СМИ Швейцарии проявляли высокий интерес к России как актору международных отношений. Несмотря на функ- ных конфликтов. ционирование массмедиа Швейцарии в условиях политической нестабильности и глобального информационного противоборства, направленного на создание образа врага в лице России, а также учитывая такие существенные недостатки редакционной политики изданий, как формирование международной повестки посредством перепечатывания сообщений из лент западных информационных агентств, журналисты исследуемых нами газет довольно полно анализировали международные конфликты с участием России и в ряде случаев высоко оценивали инициированные Россией действия по мирному урегулированию международ-

\section{Примечания}

${ }^{1}$ World Press Freedom Index. Режим доступа: https://rsf.org/en/ranking/2019

2 We speak Swiss. Режим доступа: https://bit.ly/2VcBNHR

3 Swiss Foreign Policy Strategy 2016-19: Federal Council report on the priorities for the 2016-19 legislative period. Режим доступа: https://www.eda.admin.ch/dam/eda/en/ documents/publications/SchweizerischeAussenpolitik/Aussenpolitische-Strategie_ EN.pdf

${ }^{4}$ Хронологические рамки исследования: март 2018 г. - февраль 2019 г.; метод контент-анализ и анализ по критериям «мирной журналистики» Й. Галтунга (2000); объект исследования - франкоязычные газеты Швейцарии (Le Temps, La Liberté, Le Courrier), предмет - публикации, освещающие роль России как участника международных конфликтов.

5 Switzerland. Media Landscapes. Режим доступа: https://bit.ly/2T5KGWl

6 Россия-Швейцария: документы и материалы / Министерство иностранных дел Российской Федерации и др. М.: Междунар. отношения, 1995.

7 Интервью автора с редактором международного отдела газеты Le Courrier Б. Перезом. 2019. Март, 15.

8 International humanitarian law. Swiss Neutrality. Режим доступа: https://www.eda. admin.ch/dam/eda/en/documents/aussenpolitik/voelkerrecht/Swiss\%20neutrality. pdf

9 The Propaganda Multiplier // Swiss Propaganda Research. Режим доступа: https:// swprs.org/the-propaganda-multiplier/

10 Там же. 
114 agences de presse influencent toute la population mondiale. Режим доступа: https://bit.ly/2NSSFAR

12 См., напр.: La Russie dit avoir été visée par «25 millions de cyberattaques» pendant le Mondial. Режим доступа: https://www.letemps.ch/monde/russie-dit-visee-25millions-cyberattaques-pendant-mondial; Selon Moscou, l'empoisonnement de Sergueï Skripal pouvait être «dans l'intérêt» de Londres. Режим доступа: https:// www.letemps.ch/monde/selon-moscou-lempoisonnement-serguei-skripal-pouvaitlinteret-londres

13 Из интервью с редактором международного отдела газеты Le Courrier Б. Перезом.

14 Там же.

\section{Библиография}

Быкова М.Ю. Средства массовой информации Швейцарии в контексте европейского коммуникационного процесса: дис. ... канд. филол. наук. СПб, 2001.

Драгунов Г.П. Швейцария: история и современность (Очерк новейшей истории). М.: Мысль, 1978.

Исследования СМИ: методология, подходы, методы: учеб. пособие / под ред. И.Д. Фомичевой. М.: Фак. журн. МГУ, 2011.

Краснова Е.Б. Образ России на страницах качественной газеты «Нойе цюрхер цайтунг»: дис. ... канд. филол. наук. М., 2012.

Прутцков Г.В. Средства массовой информации США (1945-1989) // История зарубежной журналистики. От Античности до современности: учеб.-метод. комплект (учеб. пособие, контрольные вопросы, хрестоматия). М.: Аспект Пресс, 2018. С. 259-277.

Тимошенко Е.Д. Анализ приемов и методов полемики в материалах швейцарской газеты «Тан»: 2007-2010 гг.: дис. ... канд. филол. наук. М., 2011.

Тиунов О.И. Вопрос о совместимости обязательств постоянно нейтрального государства с обязанностями члена ООН // Нейтралитет в международном праве: дис. ... канд. юрид. наук. Пермь, 1968. С. 57-69. Режим доступа: http://www.ex-jure.ru/freelaw/ news.php?newsid=1167

Умеренко Ю.А. Институт нейтралитета в международном праве: вопросы теории и практики: автореф. дис. ... канд. юр. наук. М., 2011.

Федотова Л.Н. Анализ содержания - социологический метод изучения средств массовой коммуникации. М.: Ин-т социологии РАН, 2001.

Фокина С.В. Основные этапы становления и развития нейтралитета в европейском пространстве (на примере Швейцарии и Австрии) // Исторические, философские, политические и юридические науки, культурология и искусствоведение. Вопросы теории и практики. 2016. № 3-1 (65): в 2 ч. Ч. 1. С. 183-187.

Якова Т.С. (а) Массмедиа и конфликты современного мира // Крылья хаоса. Массмедиа, мировая политика и безопасность государства. М.: ИКАР, 2018.

Якова Т.С. Медиаландшафт Швейцарии: слияния и поглощения на фоне кризиса // Вестн. Моск. ун-та. Сер. 10: Журналистика. 2010. № 2. С. 23-34.

Якова Т.С. Медиареальность в контексте социокультурной глокализации (на примере Швейцарии) // Медиаскоп. 2017. Вып. 4. Режим доступа: http://www.mediascope.ru/2385 
Якова Т.С. (б) Мирная журналистика» в противодействии терроризму // Медиаскоп. 2018. Вып. 3. Режим доступа: http://www.mediascope.ru/2477 DOI: 10.30547/ mediascope.3.2018.13

Якова Т.С. Онлайн-медиа в Швейцарии: тенденции и перспективы // Вестн. Моск. ун-та. Сер. 10: Журналистика. 2013. № 2. С. 91-97.

Якова Т.С. Швейцария на пути преодоления цифрового неравенства: стратегии и практики // Медиаскоп. 2016. Вып. 4. Режим доступа: http://www.mediascope.ru/2211

Aguirre M., Ferrándiz F. (2002) The Emotion and the Truth: Studies in Mass Communication and Conflict. Bilbao: University of Deusto.

Fischer T., Möckli D. (2016) The Limits of Compensation: Swiss Neutrality Policy in the Cold War. Journal of Cold War Studies 18 (4): 12-35. DOI: 10.1162/JCWS_a_00678

Galtung J (2002) Peace Journalism - a Challenge. In: Kempf W., Luostarinen H .(eds.) Journalism and the New World Order. Vol. 2: Studying War and the Media. Gothenburg: Nordicom, pp. 259-272.

Galtung J. (2000) The Task of Peace Journalism. Ethical Perspectives 7 (2-3): 162-167.

Hallin D.C., Mancini P. (2004) Comparing Media Systems: Three Models of Media and Politics. Cambridge: Cambridge University Press.

McGoldrick A., Lynch J. (2000) Peace Journalism. What is It? How to do It? Режим доступа: https://www.transcend.org/tri/downloads/McGoldrick_Lynch_Peace-Journalism.pdf

McQuail D. (2010) Media Structure and Performance: Principles and Accountability. In: McQuail D. McQuail's Mass Communication Theory. SAGE, pp. 162-183.

Postman N. (1985) "Now... This". In: Amusing Ourselves to Death: Public Discourse in the Age of Show Business. Penguin books Ltd. Режим доступа: https://bit.ly/2AJpFb7 